\begin{tabular}{|l|l|l||}
\hline \multicolumn{2}{|c|}{ PublisherInfo } \\
\hline \hline PublisherName & $:$ & BioMed Central \\
\hline \hline PublisherLocation & $:$ & London \\
\hline \hline PublisherImprintName & $:$ & BioMed Central \\
\hline \hline
\end{tabular}

\title{
Lymphocyte signaling
}

\begin{tabular}{|l|l|l||}
\hline \multicolumn{2}{|c||}{ ArticleInfo } \\
\hline \hline ArticleID & $:$ & 4225 \\
\hline \hline ArticleDOI & $:$ & $10.1186 /$ gb-spotlight-20011015-02 \\
\hline \hline ArticleCitationID & $:$ & spotlight-20011015-02 \\
\hline \hline ArticleSequenceNumber & $:$ & 296 \\
\hline \hline ArticleCategory & $:$ & Research news \\
\hline \hline ArticleFirstPage & $:$ & 1 \\
\hline \hline ArticleLastPage & $:$ & 2 \\
\hline \hline & $:$ & RegistrationDate : 2001-10-15 \\
ArticleHistory & $:$ & OnlineDate $\quad$ 2001-10-15 \\
\hline \hline ArticleCopyright & $:$ & BioMed Central Ltd2001 \\
\hline \hline ArticleGrants & $:$ & \\
\hline \hline ArticleContext & $:$ & 130592211 \\
\hline \hline
\end{tabular}




\section{Jonathan B Weitzman}

Email: jonathanweitzman@hotmail.com

During T-lymphocyte activation, signals from a number of cell-surface receptors must be integrated to ensure the appropriate genetic response. Non-dividing, primary T lymphocytes are notoriously difficult to transfect, presenting an experimental limitation to dissecting signaling mechanisms. In the October issue of Nature Medicine, Michael Bell and researchers from the Mayo Clinic in Rochester, Minnesota, describe an efficient method for introducing DNA into non-dividing lymphocytes, so as to analyze gene regulation (Nature Medicine 2001, 7:1155-1158). They optimized the conditions for transiently transfecting mouse thymocytes and human T cells. Using electroporation they achieved over $50 \%$ transfection rates while maintaining high cell viability; they then demonstrated that this transfection technology could be used to examine the effects of MAP kinase signaling. Using multiparameter flow

cytometry, Bell et al.showed that constitutively active MEK-1 MAP kinase induced expression of the anti-apoptotic protein $\mathrm{Bcl}-2$ in double-positive $(\mathrm{CD} 4+\mathrm{CD} 8+)$ mouse thymocytes.

\section{References}

1. CD28/B7 system of $\mathrm{T}$ cell costimulation.

2. Nature Medicine, [http://medicine.nature.com]

3. Mayo Clinic, [http://www.mayo.edu] 